\title{
Kannen iho, säestys ja käännös
}

\section{Ville Hänninen: Kirjan kasvot: Sata vuotta suomalaisia kirjankansia. Kirjokansi, 178. Helsinki: SKS, 2017,199 S.}

Ville Hännisen Kirjan kasvot, joka käsittelee sataa merkittävää kirjankantta Suomen itsenäisyysajan ensimmäiseltä vuosisadalta, ei edusta varsinaista kirjallisuudentutkimusta. Teoksen arviointi kirjallisuudentutkimuksellisessa aikakauslehdessä on kuitenkin perusteltua, koska se nostaa tyylikkäästi esille harvoin itsessään arvostetun, mutta näkyvän elementin kirjallista elämää. Teos antaa myös runsaasti tutkimuksellista ajateltavaa. Tietokirjailija ja toimittaja Hänninen pohtii esseissään kansien merkityksiä ja niiden taiteellisia ja yhteiskunnallisia taustoja monipuolisella otteella. Kansikuvien laadukkaat reproduktiot tuovat hyvin esiin aiheen taiteellisen kiinnostavuuden. Hänninen on tehnyt vähän tunnetun alueen peruskartoitusta myös haastattelemalla ison joukon kannentekijöitä, joiden kommentit syventävät aiheen käsittelyä.

Teoksen painopiste on kotimaisen kaunokirjallisuuden kansissa, Konrad Lehtimäestä Laura Lindstedtiin, mutta mukana on myös tietokirjallisuutta. Jälkimmäisiin lukeutuvat esimerkiksi Suomen Laki, Juhani Suomen Kekkoselämäkerta ja niinkin käyttötaidetta edustavat saavutukset kuten Spectrum -tietokirjasarjan ja CD-faktan kannet. Käännetyn kaunokirjallisuuden kannet saavat vahvemman aseman 1960-luvulta eteenpäin. Moni tuottelias kansitaiteilija on mukana kahdella kannella. Näihin kansitaiteen vaikuttajiin lukeutuvat esimerkiksi Topi Vikstedt, Alfons Eder, Urpo Huhtanen, Tapani Aartomaa, Henrik Tikkanen, Matti Louhi, Timo Aarniala, Martti Ruokonen ja Marja-Leena Muukka. Väinö Linnan Tuntemattoman sotilaan ikonisen kansikuvan ja James Joycen Odysseuksen Saarikoski-käännöksen kannen luoneelta Martti Mykkäseltä on mukana peräti kolme kantta, samoin Otavan Delfiini-sarjan kansien suunnittelijalta Kosti "Antik" Antikaiselta. Mykkäsen ja Antikin grafiikka nousee 1950-luvun modernismista ammentaen myös aikansa julistetaiteen selkeistä ja pelkistävistä linjoista. Hänninen ajoittaa suomalaisen kirja- ja julistesuunnittelun modernistisen kauden käänteen juuri Mykkäsen Tuntemattomaan. Kotimaiset kannentekijät ovat tyypillisesti olleet aktiivisia monella kaupallisen taiteen alalla. Heitä ovat työllistäneet erityisesti mainosgrafiikan tehtävät kuten lehtija kirjakuvitus, julistetaide, postikortit, pilakuvat ja sarjakuvastripit. Tekijöiden monialaisuus ja kansien asema käyttötaiteena lienevät myös syitä sille, miksi kansitaiteilijoita tunnetaan niin huonosti.

Hännisen esseet nostavat esiin useita tutkimuksen arvoisia aiheita. Yksi ilmeinen kysymys on kannen kokonaisuuden, sen typografian, kuva-aiheen ja sommitelman yhteys teoksen sisältöön. Kannella on monta samanaikaista tehtä- 
vää, joita voidaan tarkastella niin formalistis-taiteellisessa kuin historiallisessa merkityksessä. Kansi pyrkii herättämään lukijan mielenkiinnon samalla kun se tarjoaa näkökulman teoksen sisältöön muiden kynnystekstien kuten kirjailijan ja teoksen nimen, takakansikuvauksen tai moton ohella. Kansi voi korostaa, kommentoida ja tulkita teoksen nimeä, keskeistä henkilöä, tarinan elementtejä, teoksen henkeä, tyyliä tai teemaa. Näin se voi toimia myös eräänlaisena teoksen lukuohjeena. Esimerkiksi Sami Saramäen Arto Salmisen Paskateoria -romaaniin tekemä kansi, joka näyttää iltapäivälehden lööppimainokselta, johdattaa lukijaa suoraan teoksen maailmaan. Kansi myös muuttuu usein edition myötä ja ilmentää näin teoksen muuttuvaa vastaanottoa. Miten uusi kansi mahdollisesti vaikuttaa teoksen asemaan tai jopa sen lukemiseen? Kansi on olennainen teoksen näkyvyydelle ja tunnistettavuudelle, mutta se vaikuttaa myös teoksen tulkintaan, asemaan, lajimäärittelyyn ja oletettuun yleisöön.

Hännisen haastattelema kansitaiteilija Markko Taina tiivistää kannen ja kirjan sisällön suhteen kiehtovasti kolmeen perusmuotoon: kansi on kuin teoksen käännös ("se ei voi poiketa järjettömästi alkuperäisteoksesta"), mutta myös kuin musiikillinen säestys tai kirjan iho. Kannen ei kuitenkaan kannata toistaa kirjoitettua teosta tai yrittää "sanoa" sama asia. Jos kansi on kuin teoksen käännös, niin silloin sopivimmat analogiat löytyvät taiteidenvälisen adaptaatioiden muodoista tai niin sanotuista intersemioottisia käännöksiä ohjaavista periaatteista. Miten kannen multimodaalinen kokonaisuus esimerkiksi pyrkii yhdenmukaisuuteen tai samankaltaisuuteen teoksen kanssa? Kansikuva on väistämättä teoksen tulkinta; myös pelkkä typografia ja taustaväri voivat toimia tulkinnallisesti. Eräs kiinnostava seikka kaunokirjallisuuden kansissa on, etteivät ne yleensä kuvaa juonta, vaan keskeisiä henkilöhahmoja, paikkoja, tiloja, symboleita ja tunnetiloja. Juonipaljastus kannessa ei ole mielekäs ratkaisu. Toisaalta ajallisen jakson esittäminen kannen rajatussa tilassa voi olla haastavaa. Kansi myös pyrkii mainoksen tavoin vetoamaan mahdolliseen lukijaan. Sen ohella kansitaide on osa kirjan materiaalisuutta kuten kirjan muoto, koko ja muu fyysisyys (sidos, kannen ja paperin materiaalit ja niin edelleen). Tällä kaikella on vaikutusta lukukokemukseen. Kansikuvien vaikuttavuus tuntuu henkilökohtaisella tasolla Kirjan kasvot-teoksen sisältämiä kansikuvia katsellessani, kun kuvat herättävät halun tarttua teoksiin ja lukea niitä.

Monista modernien teosten kansikuvista, kuten esimerkiksi Sylvi Kunnaksen kannesta Mika Waltarin ja Olavi Paavolaisen Valtatiet -kokoelmaan tai Mykkäsen Tuntemattomasta, on tullut ikonisia teoksen kuvia. Erikoinen tapaus on myös Björn Landströmin sittemmin ikoniseksi vakiintunut kansi Waltarin Sinuhe egyptiläiseen, joka kuitenkin ilmestyi vasta romaanin 11. painoksessa vuonna 1974. Kansi voi saada teokseen eräänlaisen metonymian aseman vähän samaan tyyliin kuin "Olen lukenut Mika Waltaria" tarkoittaa "Mika Waltarin teoksia". Todella onnistunut kansi muuttuu siis teoksen osaksi, joka ei vain tulkitse teosta, vaan jota tulkitaan osana teosta. Kansikuvan ominaisuudet, grafiikka ja sommittelu selittävät osaltaan kannen menestystä. Sinuhen tun- 
netussa kansikuvassa, jonka osa toimii myös Kirjan kasvot -teoksen kantena (kuvallinen synekdokee), etualan päähenkilö katsoo tenhoavasti suoraan lukijaan. Koristeltua taustaa vasten rintakuva edelleen korostaa Sinuhen henkilökohtaista minäkerrontaa. Kenties myös teoksen menestys voi nostaa kannen merkitystä kuvallisista ansioista riippumatta?

Kysymys kirjailijan ja kansitaiteilijan yhteistyöstä on hyvä taiteidenvälisen tutkimuksen aihe, samoin kansitaiteen suhde kirjailijan tarkoituksiin. Surullisenkuuluisa tapaus jälkimmäisestä on Vladimir Nabokovin Lolita, joka on myös mukana Kirjan kasvot -teoksessa Jenni Noposen 1950-lukua henkivässä retrohenkisessä kannessa, joka voitti Grafian Hopeahuippu-palkinnon vuonna 2010. Nabokovin omia kansikuvaa koskevia ohjeita amerikkalaiselle kustantajalle Walter J. Mintonille on harvoin noudatettu ja usein suoraan rikottu. Nabokov ei toivonut kanteen perhosia, naiivia tai sarjakuvamaista tyyliä eikä missään tapauksessa kuvaa pienestä tytöstä, jollainen löytyy myös Noposen toteutuksesta. "Voisiko New Yorkista löytyä taiteilijaa", Nabokov kysyi, "joka osaisi piirtää romanttisen hienovaraisesti ei-freudilaisen ja ei-lapsellisen kannen, joka kuvaisi häipyvää etäisyyttä, pehmeää amerikkalaista maisemaa, nostalgista maantietä tai muuta sellaista?” Myöhemmin, hylättyään monta surkeana pitämäänsä ehdotusta, Nabokov vielä tarkensi: "Haluan puhtaita värejä, liukenevia pilviä, tarkasti piirrettyjä yksityiskohtia, sateen jälkeisen äkillisen auringonvalon etääntyvän tien päällä siten että valo taittuu kyntövaoissa ja tien uurteissa. Ei tyttöjä" (suomennokset minun). Sikäli jos tätä näkemystä ei voisi toteuttaa, Nabokov oli kuitenkin valmis hyväksymään kuvattoman valkoisen kannen - mieluummin karheasta kuin kiiltävästä paperista -, jossa kirjan nimi olisi painettuna isoin mustin kirjaimin. Ensipainoksen kannessa oli lopulta pelkkä otsake vihreällä taustalla. Hänninen viittaa Lolitan myöhempään kansikuvahistoriaan osuvasti pimuparaatina.

Tutkimukselle otollisia kysymyksiä ovat myös kirjankansien kulttuurihistorialliset ja ajankuvalliset merkitykset, taloudelliset kytkennät, suhde kirjan lajiin ja julkaisumuotoon sekä kansitaiteen tyylilliset kaudet ja kehityskulut. Kannella on usein kiinteä suhde julkaisuaikansa yleisempiin taiteellisiin virtauksiin sekä kirjan lajiin, tyyppiin tai käyttötapaan. Kannen suunnittelu on erilaista taidekirjassa ja tietokirjassa kuin bestseller-romaanissa. Kansityylit vaihtelevat myös genreittäin. Toisaalta kansitaide on osa kirjan markkinointia ja kirjankustantamisen trendejä ja heijastaa tässä suhteessa kustantamiseen liittyviä taloudellisia ja teknisiä reunaehtoja. Hänninen tuo esiin useita olennaisia kansitaiteen historiallisia käännekohtia ja murroksia: modernismin läpimurto 1950-luvun alussa, valokuva- ja sekatekniikoiden nousu hallitsevaan asemaan 1960- ja 70-luvuilla perinteisemmän grafiikan ja kansitaiteen kustannuksella, kuvitettujen teosten syrjäytyminen aikuisille tarkoitetusta kirjallisuudesta 1990-luvun laman myötä ja samanaikainen tietokoneen kasvava merkitys kirjan ulkoasun suunnittelussa. Näissä huomioissaan Hänninen välillisesti kirjoittaa kansitaiteen vielä kertomatonta historiaa. Huomioita olisi sopinut 
koota laajempaan johdanto- tai päätäntöesseeseen. Auki jää myös kysymys kansien kehityksestä tällä hetkellä, kun kirjoja kasvavasti luetaan tai kuunnellaan sähköisessä muodossa.

Kirjan kasvot on osa Hännisen laajempaa projektia, kansiesseiden sarjaa, jota hän edelleen kirjoittaa Parnassoon otsikolla "Kannen takana". Aiheessa riittää vielä paljon ammennettavaa. Miksei kirjallisuudentutkimus sitten ole ollut kiinnostunut kirjojen kansista? Asia on kenties koettu niin itsestään selväksi ja marginaaliseksi, ettei se ole edes juolahtanut mieleen. Toisaalta kannet ovat vahvasti ei-kirjallista esitystä. Ne sisältävät yleensä kuvia ja grafiikkaa, värejä ja muotoilua. Samalla ne ovat osa markkinointia, julkaisumuotoa ja kirjankustantamisen instituutiota. Kansitaiteen tutkimus sijoittuu väistämättä jonnekin kirjallisuudentutkimuksen, kuvantutkimuksen ja muiden alojen välialueille. Hieman sama kohtalo on ollut kirjojen kuvituksella, joka ei ole saanut ansaitsemaansa huomiota kirjallisuudentutkimuksessa eikä taidehistoriassa. Kenties uudemmat lukemisen kokemuksellisuutta, kirjan materiaalisuutta tai multimodaalisuutta korostavat tutkimustrendit vielä joskus muuttavat tilanteen.

Kai Mikkonen 